\title{
DEBATES ON CAUSALITY IN ISLAMIC KALĀM AND MODERN PHYSICS:
}

\section{A Comparison Between the Theory of Tab' and the Soft-Deterministic Interpretations of Quantum Theory*}

\author{
(D) Ahmet Mekin KANDEMİR
}

\begin{abstract}
The aim of this article is to discuss the causality concepts of Muslim scholars (mutakallimūn) in terms of modern physics theories and to shed light on the ongoing debates in this context. It is possible to say that there are three attitudes about causality in the Islamic kalām. The first one is the concepts that adopt the principle of causality based on the theory of nature (tab'); the second is the concepts of Ashārites that deny causality and explain the relations between entities in the universe with the concept of possibility based on the theory of custom ('ādah), and the third one is the understanding of the Bașra school, which accepts causality in some subjects and explains some issues with the concept of 'ādah. In modern physics, a similar divergence is seen between Newtonian determinist understandings and indeterminist understandings based on Quantum uncertainty. In some recent research, it is argued that there are significant similarities between the principle of quantum uncertainty and the theory of custom. In this article, the causality conceptions of mutakallimūn are addressed with the context of the theories of 'âdah and tab'. Then analyzes are made on the aspects of these understandings that match and diverge with the idea of causality implied by modern physics. Consequently, a new reading is suggested, taking into account modern physics, based on the theories of mutakallimūn who accept natures and causality in natural beings -especially Abū Isḥāq al-Nazzāām (d. 231/845)-.
\end{abstract}

Keywords: Kalām, Causality, The theory of nature (țab'), The theory of custom

* This work has been supported by The Scientific and Technological Research Council of Turkey (TÜBİTAK). Project Number: 1059B141600845

a Res. Asst. Ph.D., Necmettin Erbakan Üniversitesi, ahmetmekin@hotmail.com 
('ādah), Quantum physics.

$$
\text { 敌淡 }
$$

KELÂMDA VE MODERN FIZIKTE NEDENSELLIK TARTIŞMALARI:

\section{Tab` Teorisi ile Kuantum Teorisinin Soft-Determinist Yorumları Arasında Bir Karşılaştırma}

Bu makalenin amacı, kelâmcıların nedensellik anlayışlarını modern fizik teorileri açısından ele almak ve bu çerçevede süregelen tartışmalara ışık tutmaktır. İslam kelâmında nedensellik karşısında üç farklı tutumun olduğunu söylemek mümkündür. İlki tab'/tabiat teorisine dayanarak nedensellik ilkesini benimseyen tabiatçı kelâmcıların anlayışı; ikincisi âdet teorisinden hareketle nedenselliği tümüyle yadsıyan ve varlıklar arası ilişkileri imkan kavramıyla açıklayan Eş'arîlerin tutumu; üçüncüsü ise bazı konularda nedenselliği kabul eden, bazı konuları ise âdet kavramı ile açıklayan Basra ekolünün anlayışıdır. Modern fizikte ise Newtoncu determinist anlayışlar ile Kuantum belirsizliğine dayanan indeterminist anlayışlar arasında bir ayrışmanın olduğu görülmektedir. Son dönemde yapılan bazı araştırmalarda kuantum belirsizlik ilkesi ile âdet teorisi arasında benzerlikler bulunduğu, daha doğrusu kuantumun standart yorumunun âdet teorisiyle örtüştüğü savunulmaktadır. Bu makalede kelâmcıların nedensellik anlayışları tabiat ve âdet teroileri ekseninde ele alınmakta ve bu anlayışların modern fiziğin ima ettiği nedensellik düşüncesiyle uyuşan ve ayrışan yönleri üzerinde değerlendirmeler yapılmaktadır. Sonuçta varlıklardaki tabiatları ve nedenselliği kabul eden kelâmclların -özellikle Ebu İshâk en-Nazzâm'ın- anlayışından hareketle, modern fiziği de dikkate alan yeni bir okuma önerilmektedir.

[Geniş Türkçe Öz, çalışmanın sonunda yer almaktadır.]

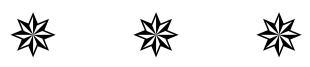

\section{Introduction}

The causality principle which states that every event has a direct or indirect cause, as a philosophical concept, expresses the relation between two natural phenomena or processes where the one cannot appear in the timeline without the other. Natural causality, as a concept, means that everything in the universe has a cause and the same causes give rise to the same effects under the same conditions, and, as a principle, states that the relationship between cause and effect is necessary. ${ }^{1}$

Since the early terms of human history, mankind has tried to

1 Richard Taylor, "Causation”, The Encyclopedia of Philosophy, ed. Paul Edwards (New York: Macmillan, 1967), 56. 
understand the nature where they live in and to explain the events and changes which occure there. For this, they investigated the causes of events they observed and made some inferences about them. Because exploring the reasons to explain an event is both a natural tendency of the human mind and an accepted method since ancient times. ${ }^{2}$ For this reason, the causality problem is one of the most important issues of the discipline of philosophy investigating existence. Questioning about "arché" made by Ancient Greek philosophers of Miletus in the history of philosophy can be considered as the first research on causality. After that, with Socrates and Plato, the theological explanation model about causality came to the forefront, but it was Aristotle (384-322 BC) who developed a systematic form of causality in the history of philosophy. ${ }^{3}$

Aristotle's theory of the four causes (material, formal, efficient and final) dominated the philosophical field for nearly two thousand years and deeply influenced Islamic philosophy throughout the Middle Ages. According to this theory, the necessary first cause of all events in the universe is God and He has caused all the events in the world to occur via intermediary reasons. For example, in a sculpture made of marble, while the marble block is the material cause, the form of the sculpture is the formal cause, the sculptor is the efficient cause, and the intended aesthetic goal is the final cause. ${ }^{4}$ With regard to causality, the second view of the philosophy of nature in the ancient Greek philosophy was represented by Democritus (460-370 BC) and Epicurus (BC 331-270 BC) who was affected by him. According to them, matter that is not created and is also indestructible is made up of atoms. According to Democritus, while these atoms act naturally and necessarily, Epicurus argued that they act accidentally. ${ }^{5}$

Although the first of these two views in Ancient Greek philosophy accepted that God is the first cause, it argued that the events occur within the cause-effect relationship. The second view denied both God and the relationship between beings. With the translation of the Greek philosophical

\footnotetext{
2 On this issue see. Ahmet Arslan, İlkçağ Felsefe Tarihi 1 Sokrates Öncesi Yunan Felsefesi (İstanbul: İstanbul Bilgi Üniversitesi Publications, 2006), 76; Hasan Aydın, Eski Yunan'dan İslam'ın Klasik Çăgına Neden Kavramı ve Nedensellik Sorunu (İstanbul: Bilim ve Gelecek Publications, 2009), 15-16.

${ }^{3}$ Aristoteles, Metafizik, çev. Ahmet Arslan (İstanbul: Sosyal Publications, 1996), 983b 5; Hüsameddin Erdem, İlkçağ Felsefesi Tarihi (Konya: Hü-Er Publications, 2010), 66-67.

${ }^{4}$ Aristoteles, Fizik, çev. Saffet Babür (İstanbul: Yapı Kredi Publications, 2005), 195a 2535, 195b 20-25.

5 Walter Kranz, Antik Felsefe: Metinler ve Açıklamalar, çev. Suat Baydur (İstanbul: Sosyal Publications, 1994), 126.
} 
heritage into Arabic, these works have paved the way for new debates as well as speeding up the debates in the Islamic world. The vast majority of Muslim scholars rejected the idea that God is only the first cause and ineffective in universe. They also rejected the conception that created beings have a causal power. On the other hand, while admitting that there is no causal power in objects, they also opposed the claim that events occurred by coincidence. ${ }^{6}$

Muslim philosophers, who were influenced by the Aristotelian Philosophy, tended to design the whole universe as a total system that had emerged from the first cause (al-'Illah al-ūlā) with a mandatory chain of causality (al-'illiyya). The first systematic expression of these understandings manifested in Al-Fārābì (d. 339/950) in the form of the theory of emanation (șudūr). ${ }^{7}$ In Ibn Sīnā's (d. 428/1037) system, it is placed within the framework of the distinction between essence and existence; material and formal causes have been classified as internal causes related to the essence and truth of the existence; efficient and final causes have been clasified as external causes for existence of result. 8

In Islamic kalām, debates on causality have emerged mostly towards the theological purposes. The first aim of these is to prove that God has omnipotence and is active in all processes related to the universe. Because, according to mutakallimūn, if the idea of determinism is accepted, it must be assumed that there are innate natures in objects and that they necessarily have some effects. In this case, even if God is accepted as the creator, his intervention in this process will not be possible and it will only be accepted as the "first reason" for the universe as with the philosophers. Another aim is to prove the possibility of miracles. According to the mutakallimūn, the difference between the prophet sent by God and the one who claims to be a prophet (mutanabbī) is miracles created by God to affirm his prophecy. For this reason, they designed the theory of causality to allow miracles. ${ }^{9}$ For these purposes, the nature of the relationship between cause and effect and

${ }^{6}$ H. Austryn Wolfson, The Philosophy of Kalām (London: Harward University Press, 1976), 520.

${ }^{7}$ Abū Nașr Al-Fārābī, Arāu ahl al-Madīna al-fāḍila, ed. A. Nasri Nader (Beirut: Dār alMashrik, 1986), 57-58, 61.

${ }^{8}$ Abū 'Alī Ibn Sīnā, Kitāb al-Shifā Metaphysic, çev. Ekrem Demirli-Ömer Türker (İstanbul: Litera Publications, 2004), 2/6-8.

9 Imām al-Haramayn Al-Juwaynī, Kitāb al-Irshād ilā kawāți' al-adilla fĩ usūl al-i'tikād, ed. Ahmad Abd al-Rahman al-Sāyih-Tavfik Ali Vahba (Cairo: Maktaba al-Sakāfe al-Dīnīyya, 2009), 262; Qāḍī 'Abd al-Jabbār, Sharḥ al-usūl al-khamsa, ed. İlyas Çelebi (İstanbul: YEK Publications, 2013), 2/431; Abū al-Mu'īn Al-Nasafì, Tabșıra al-adilla fì al-ușūl al-dīn, thk. Hüseyin Atay- Şaban Ali Düzgün (Ankara: DİB Publications, 2004), 1/690-691. 
whether the cause requires the result are discussed extensively by the Muslim theologians.

In this sense, it can be said that there are basically three different approaches to causality in Islamic kalām. These are the theory of tab' in which the principle of causality is accepted; the theory of 'ādah in which causal relationships are completely rejected, and the theories of tawlid and i'timād in which causal relationships are partially accepted. ${ }^{10}$ We will try to explain these theories in detail. But first, it should be noted that, up to the present, comparisons between mutakallimūn's concepts of causality and quantum physics have been made only on the theory of 'ādah. In this regard, studies were made at the level of books, theses, and articles, and it was suggested that there were many similarities between the theory 'âdah which formulated by Al-Ghāzālī and the Copenhagen interpretation of quantum theory. ${ }^{11}$ But neither the Copenhagen interpretation is the only quantum interpretation of causality, nor the theory of 'âdah is the only causality theory advocated by mutakallimūn. The purpose of this article, unlike previous studies, is to make a comparison between the theory of tab' which adopted by some of Mu'tazili scholars and the soft-deterministic interpretations of quantum.

\section{A. Causality in Islamic Kalām}

\section{The Theory of 'Ādah and Rejecting of Causality}

In Ash'arite kalām, it is accepted that relationships between the events observed in nature are not necessary. Their conceptions of substance, movement, space and time which shaped within the framework of atomism make it impossible to accept the causal relationships in nature. Because the ability of one atom to affect the other depends on being different in strength, quality and effect. It is not possible for atoms that are similar in all respects to have any effect on each other. Besides, the atoms that constitute objects are discrete and separated. There is a void/nothingness between them. This

\footnotetext{
10 See. Cemalettin Erdemci, Kelam Kozmolojisine Giriş (Ankara: Araştırma Publications, 2007), 119 ff.; Osman Demir, Kelâmda Nedensellik Illk Dönem Kelamcılarında Tabiat ve Insan (Klasik Publications, 2015), 182-203; 239-262.

11 See. Karen Harding, "Causality Then and Now: Al Ghazālī and Quantum Theory", The American Journal of Social Sciences 10/2 (1993), 165-177; Umit Yolsuloglu Devji, AIGhazāli and Quantum Physics: A Comparative Analysis of The Seventeenth Discussion of Tahāfut al-Falāsifa and Qantum Theory (Canada: McGill University Institute of Islamic Studies, MA Thesis, 2003); Basil Altaie, "Re-Creation: A Possible Interpretation of Quantum Indeterminism", ArXiv:0907.3419v2 [Quant-Ph] 23 Jul 2009, (2009), 1-18; Mehdi Golshani, "Islam and the Sciences of Nature: Some Fundamental Questions", Islamic Studies 39/4 (ts.), 597-611.
} 
is an issue that does not allow interaction. Lastly, the discontinuity of attributes/a'rādh don't allow for a causal relationship. Because in a system where attributes are discontinuous, the objects can't have a nature and create a natural effect, and the objects can't change their qualities by affecting each other. ${ }^{12}$ Instead, they explain all the qualities and changes in the universe through the instant and continuous creation of God. According to this, as long as God wants to characterize an object with an attribute, $\mathrm{He}$ continues to create that attribute at any moment. If He wants to qualify with another attribute, then creates that attribute. However, if He completely stops creating attributes in the object, that object will also disappear. Undoubtedly, this understanding makes all the transitive effects between the two objects impossible. Therefore, secondary reasons affecting the natural beings are rejected in this understanding. ${ }^{13}$ This understanding is called the theory of custom/'àdah.

This thought is found its systematic form in Al-Ghazālī and used against philosophers in his Tahāfut. Al-Ghazālī, in this work, defends that the causal connections between causes and effects are not necessary and the existence of one does not require the existence of the other just as the nonexistence of one does not require nonexistence of the other. For example there is no causal relationship between drinking and quenching of thirst, eating and satiation, contact with fire and burning, the appearance of the sun and light, decapitation and death, drinking of medicine and getting better, and so on. It is because of the custom of God ('ädah/sunnah) that these things are created in succession. According to the theory of 'a dah things can not influence the other. Every kind of condition and changes and relationships between cause and effect in the universe are created personally by God. Things reveal the effects but not because of its nature, only with the creation of God. However, since this creation of God has occurred within a certain order and custom, it is observed that there is a connection between cause and effect. But it is possible for God to not create a result although there would be a cause, that he creates a result without cause, or creates the exact opposite of the cause-effect relation that we are accustomed to. ${ }^{14}$ Al-Ghazāli has criticized the philosophers to prove the possibility of miracles. Because,

${ }^{12}$ See. Mehmet Bulğen, Kelam Atomculuğu ve Modern Kozmoloji (İstanbul: Türkiye Diyanet Vakfi Publications, 2015), 310-311.

13 Alnoor Dhanani, "Atomism in Islamic Thought", Encyclopaedia of the History of Science, Technology, and Medicine in Non-Western Cultures, ed. Helaine Selin (Dordrecht: Springer Netherlands, 2008), 380.

${ }_{14}$ Abū Hāamid Al-Ghazālī, Tahāfut al-falāsifa, ed. Mahmut Kaya-Hüseyin Sarıoğlu (İstanbul: YEK Publications, 2014), 337-339. 
according to him, miracles are impossible for those who accept that the normal process of events is necessary and deterministic. ${ }^{15}$

\section{The Theories of Tawlîd-I'timād and Partial Acceptance of Causality}

The majority of Mu'tazilī scholars have accepted the causality principle to a certain extent in natural events while they have an atomic point of view. For instance, according to the theory of tawlid (indirect acts) developed by the Bașra school, there is a necessary relationship between human acts and their ongoing consequences in inanimate beings, as in the example of the action of turning the key makes it necessary to open the door. ${ }^{16}$ That is, they acknowledge that humans and objects may be the secondary cause of movements, attributes, and changes in the universe. ${ }^{17}$ But, the necessity of the consequence depends on the availability of the location and the removal of obstacles. The cause necessitates the effect in all cases where the conditions are appropriate, otherwise it does not. ${ }^{18}$ What necessitates the verbs that occur through tawlid here, is the result of the agent's will and power.

The concept of i'timād (power/resistance/inclination) is another term which shows that Bașra school accepts causality. This concept is used to explain some physical events such as pushing, pulling, pressure, resistance, etc. occurring between objects. Some natural interactions such as burning of fire, flowing of water, falling of a stone and pulling magnet are explained by this concept. The most important thing revealed by this concept is that an object can effect another. In this regard, Bașra school accepts that as a general principle, it is possible to form i'timād outside the locality. ${ }^{19}$ It can be said that the Basra school of Mu'tazilah rejected through this concept, the essentialist/naturalist thoughts which argued that objects act by necessity due to their structure. This is because, accepting that events have occurred as a result of the nature of things, according to him, makes it necessary to accept that everything that is called a blessing for the creatures is an act of nature. This makes it meaningless to bring evidence for the existence of a

15 Al-Ghazālī, Tahāfut, 337, 343; For detailed information about the theory see. Demir, Kelâmda Nedensellik, 147 ff.

${ }^{16}$ Qāọī 'Abd al-Jabbār, Kitāb al-Tawlīd min kitāb al-mughnī, ed. Osman Demir (İstanbul: Klasik Publications, 2015), 74, 115, 180.

17 Munā Ahmad Abū Zayd, al-Tasawwur al-dharrī fĩ al-fikr al-falsafí al-Islāmī (Beirut: alMuassasa al-Jâmiiyya, 1994), 266.

18 Qāḍi 'Abd al-Jabbār, al-Tawlīd, 80, 85, 114.

19 On this issue see. Demir, Kelâmda Nedensellik, 187 ff. 
wise and glorious creator regarding the universe. ${ }^{20}$

In the understanding of Bașra school, the cause-effect relationship is not deterministic in all circumstances and situations, since there is no situation related to the essence of the cause, as in the doctrine of 'illiyyah. The necessity of the relationship between cause and effect depends on some other conditions such as the suitability of the place (mahall) and the absence of obstacles. Missing one of these conditions will prevent the result from realizing. On the other hand, they argued that some events occurred with the custom of God, without any compelling reason. For example, the situation is somewhat different in the cases of drink-drunkenness, medicine-health and poison-death. There is no compulsory relationship between them. In such cases, the results are not due to causality and nature, but due to the custom of God. ${ }^{21}$

In this way, the Bașra school aims to base the miracle. However, their understanding of custom and the understanding of Ash'arites are quite different in their results. Because it means that God can intervene constantly in the universe- including miracles- in the Ahs'arites, while in Bașra school He will never intervene in natural functioning of universe -except miracles.22 This approach distinguishes them from both occasionalist understandings and strict-deterministic theories. Therefore, it would be better to describe their causality thought as a new comment between determinism and occasionalism. ${ }^{23}$

\section{The Theory of Tab' and Acceptance of Causality}

In early kalām, some Mu'tazilī scholars have accepted that, unlike atomism, there are certain natures (tabāi') inherent in the beings. But, the acceptance of natures is considered as the acceptance of causality in nature by the majority of Muslim theologians. ${ }^{24}$ In this regard, Mu'ammar b. 'Abbād

20 Qādī 'Abd al-Jabbār, al-Tawlīd, 29, 36, 44-47, 68.

21 Qāḍi 'Abd al-Jabbār, al-Tawlīd, 146; Qāḍī 'Abd al-Jabbār, Kitāb al-Macmū' fí al-muhīt bi al-taklīf 1, ed. J. J. Houben (Beirut: Matba'a al-Katūlīkiyya, 1962), 92-93; Abū Rashid AlNīsābūrī, Kitāb al-Masāil fī al-khilāf bayna al-Basriyīn wa-al-Baghdādiyyīn, ed. Ma'an Ziyāda-Ridwān al-Sayyid (Beirut: Ma'had al-Anmā' al-'Arab̄i, 1979), 148; On this issue see. Ahmet Mekin Kandemir, Mu'tezili Düşüncede Tabiat ve Nedensellik (İstanbul: Endülüs Publications, 2019), $248 \mathrm{ff}$.

22 Demir, Kelâmda Nedensellik, 157-158; Fethi Kerim Kazanç, Kâdî Abdülcebbâr'da Nedensellik Kuramı (Ankara: Araştırma Publications, 2014), 266, 269.

23 Osman Demir, “Determinizm ve Okasyonalizm Arasında: Mu’tezile'de Tevlid Düşüncesi |698| ve Ehl-i Sünnetin Eleștirisi”, Marmara Üniversitesi Illahiyat Fakültesi Dergisi 36 (2014), 82. ${ }^{24}$ See. Abū 'Imran Mūsā Ibn Maymūn, Dalālat al-ḥāirīn (Ankara: AÜíF Publications, 1974), 202, 203; Wolfson, The Philosophy of Kalām, 559-560. 
al-Sulamī (d. 215/830), Abū Isḥāq al-Naz̧āām (d. 231/845), Abū 'Uthmān alJāhịiz (d. 255/869) and Abū al-Qāsim al-Ka'bī (d. 319/931) are coming at the beginning of those who defend that the relationship between cause and effect is necessary in Mu'tazilah. Because they all accepted the theory of nature and therefore they were named as naturalists (ahl al-țabāi'). ${ }^{25}$

One of the first to accept the relationship between cause and effect in Islamic thought is al-Naz̧āam. According to him, everything has been created with a certain nature (țab') and the functioning is in accordance with the law of order and causality in the universe arising from these natures located in the entities. Accordingly, the nature of the light things (e.g. fire) is to rise, and the nature of the heavy things (e.g. stone) is to fall down. Therefore, whenever the light thing is released, it rises due to the nature that God has placed on it and reaches the highest point in the world. When something heavy is released, it comes down to the lowest point in the world due to the nature that God has placed in it. ${ }^{26}$

On the other hand, in al-Nażāām's philosophy of nature, the nature of beings is not necessary in any case. Because these natures are not the qualities of the beings themselves. These were created by God in the beginning. Therefore, the acts that occur by force of natures are accepted by al-Nażām as the acts of God because He is the distant cause of everything. For example, God has given the stone a stony nature, so it goes away when thrown. Although the act of throwing belongs to the person who throws the stone, movement of stone is the act of God who gave it this nature. ${ }^{27}$ In other words, every act that takes place in the universe belongs directly and firstly to the nature of things; but indirectly and secondly to God.

These thoughts of al-Naz̧āam do not mean that he advocates the concept of re-creation like Ash'arites, as it is claimed. ${ }^{28} \mathrm{He}$ does not actually have an occasionalist understanding of the universe. In order to understand the difference of his thought, it is necessary to look at his theory of "kumūnzuhūr". According to him, refusing the classical atomistic doctrine of kalām, the atoms (jawāhir) are formed from the accidents and the atom accepts to

25 Qāọī 'Abd al-Jabbār, al-Macmū', 406.

${ }^{26} \mathrm{Abu}$ al-Husayn Al-Khayyāț, al-Intișār wa al-radd 'alā Ibn al-Rāwandī al-mulḥid, ed. H. S. Nyberg (Beirut: Makta al-Dâr al-'Arabiyya li al-Kitâb, 1993), 40; 'Abd al-Qāhir AlBaghdādī, al-Farq bayn al-firaq, ed. M. Uthmān Al-Husht (Cairo: Maktaba Ibn Sīnā, 1988), 125; Qāọī 'Abd al-Jabbār, Sharḥ, 2/143; Abu al-Fatḥ Al-Shahristānī, al-Milal wa al-niḥal, ed. Abū 'Ali Mahnā-'Ali Hasan Fā'ūr (Beirut: Dār al-Ma'rifa, 1993), 88.

${ }^{27}$ Al-Khayyāț, Al-Intișār, 45; Qāọī 'Abd al-Jabbār, al-Tawlīd, 18; Al-Shahristānī, al-Milal, 69.

28 Alnoor Dhanani, The Physical Theory of Kalām: Atoms, Space, and Void in Basrian Mu'tazilī Cosmology (Leiden: Brill, 1993), 43. 
be divided forever. ${ }^{29}$ God has created the whole universe in a moment and concealed (kumūn) the things into each other at the time of this first creation. Priority and posteriority are not at the creation of the beings but at their emergence. At the moment of this first creation certain attributes have been placed in the bodies. All changes in things are due to these natures. All these changes that have arisen afterward are not a new creation (hudüth) but the emergence (zuhūr)..$^{30}$

It is quite obvious that this understanding is completely different from the the thought of continuing creation from nothing ('adem) of Ash'arites. It should be noted, however, that al-Naz̧āam is not a strict determinist too. Because he acknowledges that the causal laws in natural things are placed in the structure of beings by God and that He can intervene whenever wish. ${ }^{31}$ This approach shows that he had a concept of the universe which opens to divine intervention.

Al-Jāhịiz, as a student of al-Naẓzām, has common views with his teacher on nature and causality in the universe. But Mu'ammar's and al-Ka'bì's understanding of cosmology is a little different. When his theories of the atom (jawhar) and the accident (a'rādh) are analyzed, it seems that Mu'ammar accepted that God is the creator of all beings and brought them out of existence. But the role of God in the universe is limited to the creation of atoms and objects in his thought. ${ }^{32}$ According to him, God created objects with a specific nature that would create certain accidents at the time of first creation. All subsequent events and changes are described as objects' actions, by following the principle of causality in nature. In other words, God is considered as the "First Cause" in terms of being the creator of all beings, but He is regarded as a secondary/distant cause in that He creates natures which determines the actions of beings and their way of functioning. Al-Ka'bi similarly defends a deterministic causality in the realm. According to him, God acts in accordance with the law of causality, which He has set. Therefore, it is not possible for God to create direct movement or rest in beings without creating a cause. Likewise, it is impossible for God to move a heavy object directly by his own intervention or to immobilize it in the air without using

\footnotetext{
${ }^{29}$ al-Khayyāț, Al-Intișār, 33-36; Abū Al-Hasan al-Ash'arī, Maqālāt Al-Islāmiyyīn Wa Ikhtilāf al-Mușallīn, ed. M. Muhyiddin Abdülhamid (Cairo: Maktaba al-Nahdiyya al-Misriyya, 1955), 2/16.

30 Al-Khayyāṭ, Al-Intișār, 44; Al-Baghdādī, al-Farq, 128-129; Wolfson, The Philosophy of Kalām, 499.

31 Al-Khayyāț, Al-Intiṣār, 44-45.

32 Al-Khayyāț, Al-Intișār, 53-54; Al-Ash`arī, Al-Maqālāt, 2/232.
} 
any other being or occasion. 33

This kind of strict determinist thought seems to be problematic in terms of Islamic belief. Because this understanding is incompatible with the belief of a god who is constantly involved in the world, and it is not easy to base miracles in this approach. For this reason, naturalist mutakallimūn have faced with intense criticism of both Bașra school and Ahl al-Sunnah. However, these criticisms are not valid for al-Naẓzām and Al-Jāhịiz. Because they stressed that when God wills, He can create opposite acts to natures and thus $\mathrm{He}$ can interfere with the universe. It is not difficult to base miracles in this understanding. However, in Muammar and Al-Ka'bī's system, miracles can only occur in accordance with the principle of causality and the nature of beings and the same limitation applies to other divine acts.

Al-Mātūrīdī (d. 333/944), one of the leaders of Ahl al-Sunnah, accepts that there are innate natures in beings and uses frequently the concept of nature (țab') for both living and inanimate beings. According to him, God created human beings, and animals, and inanimate beings with natures that allow them to survive, protect themselves from danger, and know what is useful for them. With the help of these natures, beings are born with the necessary knowledge and equipment for behaviors such as flying, swimming, crawling, self-defense, and reproduction. ${ }^{34}$ Concerning inanimate beings, $\mathrm{Al}-$ Mātūrīdī admits that it is the nature of burning in fire, cooling in the snow, falling in stone, saturation in water and food; but emphasizes that these are not the qualities acquired by themselves, but placed within them by God. ${ }^{35}$ Despite these statements, there is controversy over whether he accepted causality or not. ${ }^{36}$ In our opinion, Al-Mātūrīdì does not adopt the theory of țab' as a doctrine, but accepts a weak understanding of causality that cannot exclude divine intervention. Because although he criticized many of his contemporary Mu'tazilī scholar Al-Ka'bī's views, he never criticized his understanding of causality. This supports the thesis that he has a positive approach to natural causality unless it does not imply the eternity of the world and does not exclude the existence of God and His intervention in

\footnotetext{
${ }^{33}$ Al-Nīsābūrī, al-Masāil, 196; Al-Shaykh al-Mufīd, Awāil al-maqālāt, thk. Ibrāhim al-Anșārī (Mashad: al-Mu'tamar al-'ālam, 2000), 129.

${ }^{34}$ Abū Manșūr Al-Mātūrīdī, Ta'wilāt al-Qur'ān, ed. Bekir Topaloğlu (İstanbul: Dār al-Mīzān, 2005), 8/141.

35 Abū Manșūr Al-Mātūrīdī, Kitāb al-Tawhīd, ed. Bekir Topaloğlu- Muhammed Aruçi (İstanbul: TDV Publications, 2001), 231; Al-Mātūrīdī, Ta'wilāt al-Qur'ān, 7/383; 9/404$405 ; 11 / 226$.

36 For these discussions see. Nazif Muhtaroglu, "Al-Mātūrīdī's View of Causality", Occasionalism Revisited (Abu Dhabi: Kalam\&Research Media, 2017), 3-4, 11-13.
} 
nature. ${ }^{37}$ However, his view of causality was not maintained by the scholars of the sect after him, but the understanding of the Al-Ash'arīs was followed instead. ${ }^{38}$

The debates of causality ongoing around "nature-custom" theories between Muslim scholars continue between the conception of the Newtonian determinist universe and the concept of uncertainty of Quantum physics. While defending determinism being supported by the science in the intellectual circles, that the Newtonian physics is dominated by a philosophical understanding based on the deterministic model, the movements and individuals who oppose this idea are criticized and the attitudes of the philosophers are welcomed positively. There is a common understanding going back to Aristotle that he puts forward that science cannot be done without accepting determinism and it is suggested that rejecting of causality harms the scientific developments. However, in order to test the accuracy of these claims, it is necessary to examine how causality is perceived in modern physics.

\section{B. Causality in Modern Physics}

Classical physics gives us a deterministic picture of nature. For instance, in the mechanics of Newton's (1642-1712), law of universal gravitation, action-reaction laws and motion laws imply that the causality principle is in effect at all times. Therefore, it is possible to pre-calculate all events in a physical system by the causality law, and to determine all the results from the reasons if an initial state and external influencing factors are known. ${ }^{39}$ In other words, in Newtonian physics, the universe is like a giant clock that operates mechanically. Accordingly, each atom follows a path which is determined by the forces acting on it. The forces in question are determined by other atoms, and so on. There is a fixed cause and effect relationship, from the smallest molecular motion to the explosion of the greatest galaxy and everything is determined to the finest detail

\footnotetext{
37 Kandemir, Tabiat ve Nedensellik, 244. For causality concept of Al-Mātūrīdī, see also. Alnoor Dhanani, "Al-Mâtûrîdî and Al-Nasafî on Atomism and the Tabâi", Büyük Türk Bilgini İmâm Mâtûrîdî ve Mâtûrîdîlik, ed. İlyas Çelebi (İstanbul: M.Ü. İlahiyat Fakültesi Vakfı Publications, 2012), 69-72; Yusuf Şevki Yavuz, "Mâtûrîdî'nin Tabiat ve İlliyete Bakışı", Büyük Türk Bilgini İmâm Mâtûrîdî ve Mâtûrîdîlik (İstanbul: M.Ü. İlahiyat Fakültesi Vakfı Publications, 2012), $59 \mathrm{ff}$.

38 Al-Nasafī, Tabșıra, 1/81-82, 96, 431-432; See also. Dhanani, "Al-Mâtûrîdî and Al-Nasafî on Atomism and the Tabâi', 73-76; Yavuz, "Mâtûrîdî'nin Tabiat ve İlliyete Bakıșı", 58-59, 62-63.

39 Max Planck, Modern Doğa Anlayıșı ve Kuantum Teorisine Giriş, çev. M. Yılmaz Öner (İstanbul: Spartaküs Publications, 1996), 38.
} 
beforehand. 40

The 18th century French mathematician and physicist Pierre Simon de Laplace (1749-1827), with reference to Newtonian mechanics, suggested that every act in the world, from the greatest objects to the smallest atoms, could be calculated if all locations and movements of the particles in the universe were fully known. ${ }^{41}$ This concept of the deterministic universe, which is compatible with Aristotle's philosophy, was accepted until the beginning of the twentieth century. However, with the emergence of the quantum theory, this picture has begun to change.

\section{Quantum Mechanics and the Principle of Uncertainty}

The concept of "quantum" has entered the science literature with Max Planck's (1858-1947) demonstration that light diffused in the form of energy packs. However, the effects of this hypothesis on causality are understood with the uncertainty principle put forth by Werner Heisenberg. ${ }^{42}$ According to this principle, it is not possible to determine both the location and the momentum of an atom or a particle at the same time. In other words, with regard to this princible, the position can not be determined when the speed of an electron is measured; the speed can not be measured when the position is detected. Therefore, it is impossible to determine both the position and the speed of an electron at the same time. ${ }^{43}$ Thus, the uncertainty principle led to critical questioning on the deterministic universe model, because if the state of the universe (speed and position) cannot be measured precisely at a moment, it will not be possible to predict future events. ${ }^{4}$

Considering the uncertainty principle, a particle can follow more than one path, so it is impossible to know in advance what path it will follow. The only thing one may know is that the particle is likely to go from one way or another. In other words, there is no single and definitive result for an observation based on quantum mechanics; but there are possible results. ${ }^{45}$ The determination of this feature of the matter has been possible by the wave-particle dilemma discussions on the nature of the light, and these debates have been influential in the emergence of quantum physics. Newton

40 Paul Davies, Tanrı ve Yeni Fizik, çev. Barış Gönülşen (İstanbul: Alfa Publications, 2013), 181.

41 Davies, Tanrı ve Yeni Fizik, 181.

42 Stephen Hawking, A Brief History of Time (New York: Bantam Press, 1996), 46-47.

43 John Polkinghorne, Quantum Theory A Very Short Introduction (New York: Oxford University Press, 2002), 32-33.

44 Hawking, A Brief History of Time, 47-48.

45 Hawking, A Brief History of Time, 48-49. 
and his colleagues argued that light is possessed of particle properties. However, a contemporary physicist with Newton, Christian Huygens (16291695) theorized that light is a wave. ${ }^{46}$

The experimental proof of this theory came from Thomas Young's (1773-1879) double slit experiment. It is placed in a plate with two holes in front of a curtain in the Young experiment. Firstly, the left hole is closed and a beam of light is sent to this plate. When only the right hole is open, there is only one trace on the screen. Then the left hole is opened and the right hole is closed, but the same result is obtained: a single trace appears on the plate. However, when two holes are opened together, the situation is a bit confused. In this case, if the light consisted of particles, one part of the light would pass through the right, one part through the left hole, and two separate patterns would form, but this is not the case. The emerging image on the plate was the "interference" pattern of light beams emitted from the source. In other words, there were many light patterns and dark patterns on the screen. Even when the same experiment was carried out with electrons and electrons were sent one by one, this interference pattern was observed. 47

In other words, it is understood that the packets of light and electrons sent from the source pass through both the right and left holes. That is, the light showed wave characteristics in these experiments. However, when a detector is placed in front of the two holes to detect the particles passing through the hole, the interference pattern on the plate disappears and two separate shapes emerge and this indicates that the light acts like a particle. This is because, there is a need for a photon to observe the electron and this changes the movement of electrons. That is, observing which particle passes through, destroys the superposition state which the fragment passes through both slits at the same time, and the particle begins to pass through a single slit. This is called as the collapse of the wave function. Because of these properties, it is accepted that light and matter behave both as waves and particles.

\section{Quantum Entanglement (Nonlocality) and Remote Effect}

The most staggering consequences of the quantum physics related to causality are datas obtained from experiments on localism and remote

46 John Gribbin, Schrödinger'in Kedisinin Peşinde, çev. Nedim Çatlı (İstanbul: Metis Publication, 2005), 23-24.

47 For detailed information and versions of experimentation with bullet, water and electron refer to Richard Feynman, The Character of Physical Law (USA: M.I.T Press, 1985), $130 \mathrm{ff}$. 
effects. In classical physics, every phenomenon has a cause and its consequences must be conjuncted in space. Quantum mechanics, however, has shown that two particles can affect each other at a distance without any connection in spacetime. This is a violation of the causality principle in classical physics. For example, according to quantum physics, in a system at the atomic level, two particles continue to affect one another remotely, even if they are separated from one another and they have moved away. Measurement made on a particle also affects the other. Einstein (1879-1955) and his colleagues arguing its contradiction to common sense suggested a mental experiment, to show the impossibility of this. In accordance with this mental experiment, which was published in 1935 and known as the EPR (Einstein-Podolski-Rosen) experiment, it is assumed that a particle is divided into two by explosion. According to quantum theory, these two particles will continue to affect one of them as far as one goes away. For instance, if one turns clockwise, the other will react in the opposite direction. If whichever the wave function collapses during observation, the appropriate condition will occur in the other. ${ }^{48}$

Einstein wanted to show the absurdity and impossibility of this situation, which is called the ghost effect by him. This is because it is contrary to the classical laws of physics (the principle of relativity) that of affecting two things which are not in physical contact with each other (violation of the principle of locality) or two particles which separated from each other by light years. So nothing in space can make a connection between two seperate particles at the same time. For many years it has not been possible to test this mental experiment. In the 1960s, however, John Bell (1928-1990) offered theoretically a way of carrying out this experiment and finally in 1982, Alaine Aspect and his colleagues conducted these experiments using the polarizations of the photons. In the experiment, photon pairs were used. According to quantum physics; if one's polarity is vertical the other will be horizontal for emitted photon pairs, no matter how far one is from another. Aspect experiments have fully identified this situation and have found that the locality principle has been violated at the quantum level. ${ }^{49}$

The problem brought up by the quantum entanglement that how two things are located at different points in the space-time and have no communication between them can effect each other, can be solved with the

${ }^{48}$ Stephen Hawking, The Universe in a Nutshell (London: Bantam Press, 2001), 123-124.

49 Roger Penrose, Büyük, Küçük ve Insan Zihni, çev. Cenk Türman (İstanbul: İzdüşüm Publications, 2005), 81-82; John Gribbin, Schrödinger'in Yavru Kedileri: Gerçekliğin Peşinde, çev. Nedim Çatlı (İstanbul: Metis Publication, 2008), 42-43. 
principle of quantum holism. According to this principle, the whole is more than the sum of its parts. It is not a simple sum of all parts. ${ }^{50}$ The quantum entanglement is important in terms of showing that the matter can not be explained in a reductive manner, that is to say, the atom can not be explained for by the sum of its particles. ${ }^{51}$ Because the whole is different and more than the sum of its parts. ${ }^{52}$ Therefore, it is not accurate to arrive at a conclusion regarding the nature of the parts from the observations of the whole, nor to make a conclusion about the whole from the nature of the part. Taking into consideration of the causality, it should be assumed that there are causal relations and regular operations in the macro-phase. However, based on this, it can not be argued that this causality relation originated from the nature of the matter.

\section{The Copenhagen Interpretation and the Theory of Custom}

The "uncertainty principle" is a key concept to understand the consequences of quantum theory which related to causality. This is because uncertainty or, in other words, undeterminacy is interpreted as a violation of the "causality principle" at the quantum level. However, while there is a consensus among physicists that classical physics draws a deterministic universe table, it must be said that there are many mutually incompatible interpretations about the results of quantum physics.

Heisenberg and The Standard Interpretation of Quantum Physics argue that this uncertainty does not originate from our ignorance or conceptual inadequacy, but on the contrary, it is a characteristic of the inner mechanism of nature. ${ }^{53}$ According to this idea, known as the Copenhagen Interpretation, entities such as electrons are real only when they are observed. There is no speed and position of the electron, and it does not have a real existence until the observation is made; it just consists of some possibilities. With observation one of these possibilities occurs and the electron becomes a real entity. Hawking is one of those who argues that quantum indeterminacy does not originate from experimental or conceptual inadequacy or hidden variables, on the contrary it originates from the nature of the matter. He even said, "Even God is constrained by this uncertainty

50 Abdullah Verçin, "Harekete İki Farklı Bakış: Determinizm ve Atomizme Karşı Olasılıkçllık ve Bütünlükçülük", Popüler Bilim 51/ (2001), 8.

51 Caner Taslaman, Kuantum Teorisi, Felsefe ve Tanrl (İstanbul: İstanbul Publications, 2008), 81.

52 Gribbin, Schrödinger'in Yavru Kedileri, 34-35.

53 Werner Heisenberg, Physics and Philosophy (London: Penguin Books, 2000), 23-35; Ian G. Barbour, Issues in Science and Religion (USA: Prentice-Hall, 1966), 303. 
principle and can not know the same position and speed; it can only know the wave function". 54

The Copenhagen Interpretation has been received positively by theist circles and has been embraced with the idea that it facilitates explaining divine activities, especially miracles. It is also possible to see the reflections of this approach in the Islamic world in studies defending a similarity between the Copenhagen Interpretation and the theory of 'ādah. We would like to briefly touch these studies and the ideas they defend.

Karen Harding, an American chemist, described many significant similarities between Ghazālī's theory of custom and the Copenhagen Interpretation of quantum theory in her article published in 1993. According to her, it is accepted in both the custom theory and the Copenhagen interpretation that objects do not have innate natures. In custom theory, all qualities related to objects are created by God. In the Copenhagen interpretation, objects do not have any quality before the observation and with observation one of the possibilities occurs. The main difference here is, in custom theory, qualities of the objects are accepted as a result of God's acts of creation while as a consequence of the interaction of the object with the observer in the Copenhagen interpretation. ${ }^{55}$

Both the Copenhagen interpretation and the custom theory do not accept that there is a necessary causal relationship in nature and events can be predicted precisely in advance. According to the Copenhagen interpretation, objects at the subatomic level do not have a real existence without any interaction, but only have a potential entity. For this reason, it is not possible to accept that objects have no qualities affecting one of them. In addition to this, both the Copenhagen interpretation and the custom theory accept the orderly functioning of the nature. According to the custom theory, this is because of the habit of God. As for the Copenhagen interpretation, there is a regular functioning and the events can be predicted with certain probabilities in nature, since some events are more likely to occur than others. These high possibilities leave place in the custom theory for "the will of God". In this case, miracles are examples of God behaving outside his own habits. ${ }^{56}$

Iranian Muslim physicist Mehdi Golshani defends a similar view. According to him in the standard interpretation of quantum mechanics an

54 Hawking, The Universe in a Nutshell, 107.

55 Harding, "Al Ghazālī and Quantum Theory", 173-174.

56 Harding, "Al Ghazālī and Quantum Theory", 175-176. 
electron has no inherent properties. This is coherent exactly with the Asharites' occasionalist view. So, they think that all attributes associated with objects are the results of God's action. That is, two schools both deny any necessary connection between cause and effect. Moreover, objects have independent existence and the events are not exactly predictable in both the Asharites' occasionalist view and the Copenhagen interpretation of quantum theory. Golshani says that the approaches of Muslim philosophers on causality are similar to those who advocate the causal interpretation of quantum theory. Likewise, their criticisms of the causality interpretation are very similar to Einstein and Bohm who criticize the interpretation of Copenhagen. ${ }^{57}$

Devji also found that there are important similarities between the two thoughts in his thesis, which compares quantum physics with Ghazālī's understanding of causality. Some of these similarities are that there are no inherent attributes in the nature of objects, the impossibility of perceiving nature and the object as it really is, and that both thoughts bring fundamental criticisms that would undermine the established perception of causality in their own time. ${ }^{58}$

Jordanian Physicist Altaie offers a new perspective on this issue. He suggests that quantum causality and attributes in entities can be defended together and consistently. According to him, co-observations of recurrence and regularity in natural phenomena point out that the existence of laws have an effect on them. Because the universe does not maintain its presence open to all probabilities in a coincidental manner, on the contrary, it functions regarding to predetermined rules. The occurrence of events in the universe takes place with the causality chain. That is why there is an effect on the result. The effect of causes on results stems from the fact that objects have a number of attributes that one can observe. These attributes are essential qualities for the substance and energy forms in the universe. ${ }^{99}$ That is to say, the innate properties of entities have the ability to interact, but these interactions must be accepted as possible, not as necessary. These attributes

57 Golshani, "Islam and the Sciences of Nature: Some Fundamental Questions", 188.

58 Devji, AI-Ghazāli and Quantum Physics: A Comparative Analysis of The Seventeenth Discussion of Tahāfut al-Falāsifa and Qantum Theory, 100-101.

${ }^{59}$ For example, the quality of fire is burning because it is energy. Therefore, it is possible to make a change in the cotton. That is, it is possible to burn objects when the energy of fire reaches the level of ignition. If it does not reach that level it will not be possible to burn. This is only one of countless laws that manage the structures in the world. See Basil Altaie vd., "Mafhūm al-sababiyya fī al-fizyā al-mu'āsira wa 'inda al-mutakallimīn almuslimīn", Kutadgu Bilig 23/ (2013), 289. 
are constantly recreated by God in accordance with the energy level of the system. The influence of these qualities is also differentiated by the recreation, and as a result the causal event is regarded as a new situation. This allows the continuation of indeterminist causal relations among the components of the universe. 60

Altaie argues that, if the assumption of continuous recreation is accepted, it may be possible to conceive a universe which is compatible with the conclusions of quantum theory and it allows for divine efficacy and excludes the idea of strict determinism. It can be explained that this is because the uncertainty that arises in quantum physics when measured quantities such as position and velocity, energy and time are simultaneous with the idea of continuous recreation. In addition, the assumption of recreation of the innate attributes of entities allows the existence of indeterministic causal relations and thus it allows all events in the natural world to be linked to one another. This is also part of the holistic entanglement of the universe implied by some interpretations of quantum physics. ${ }^{61}$ On the other side, Altaie states that the concept of continuing recreation brings a solution to the paradoxes arising from quantum measurement. This is because, this idea does not take into account the subjective role of the observer in a measurement or collapse of the wave function. These are regarded as direct results of the recreation. ${ }^{62}$ In this perspective, there is not denial of causality, but causal relations are accepted, at the same time divine power and will are fully approved. This understanding of causality also gives the opportunity to explain the effective roles of blind laws in the natural world. 63

In our opinion, it is not coherent suggestions both to establish a similarity between the theory of 'àdah and the Copenhagen interpretation, and to defend the nature of beings with continuous creation. Since, while all the qualities that the object possesses, in Islamic thought, are a result of God's creation, and the orderly functioning proper to these qualities are accepted as God's habit, but these are explained by the influence of the observer in the Copenhagen Interpretation. There is a significant difference in this regard, and it is clear that the role assigned to the observer is contrary to the Islamic belief. Moreover, in Islamic kalām, The regular functioning of the universe

60 Basil Altaie, God, Nature, and the Cause: Essays in Islam and Science (USA: Kalam\&Research Media, 2016), 82-83.

61 Altaie, God, Nature, and the Cause, 82.

62 Altaie, "Re-Creation: A Possible Interpretation of Quantum Indeterminism", 16.

${ }^{63}$ Altaie, God, Nature, and the Cause, 84. 
provides evidence for the existence and wisdom of God. But in a universe where everything is recreated at any moment, it is not possible to talk about the essence of the objects, and their qualities, and verbs, as well as a reliable order. Neither the theory of custom nor the Copenhagen interpretation provides the idea of an order that will serve as the basis for proof of God. But a soft-deterministic interpretation of the universe that allows divine intervention can provide this basis.

\section{Soft-Deterministic Interpretations of Quantum Uncertainty}

The Copenhagen Interpretation is not the only interpretation of Quantum physics on causality. According to Einstein, Bohm (1917-1992), Planck, and de Broglie (1982-1987), the uncertainty in the quantum field originated from our ignorance and illiteracy of certain laws that prevail in this area. For example, one can not predict which face of a tossed coin will fall. However, he could have guessed it if he had very detailed knowledge about the coin and the toss, like the weight of coin, the force and direction of the throw, the resistance of wind and so on. In fact, the system is deterministic itself, but there is uncertainty for us due to our information on this area is still insufficient. Then the probability structure in quantum refers to an epistemological situation rather than an ontological one. ${ }^{64}$ In other words, there is no uncertainty in the nature of the matter, on the contrary, our knowledge on this subject is insufficient yet. According to those who advocate this view, there are more detailed atomic mechanisms operating with strict causality laws. In the future, this mechanism will be discovered and precise predictions will be possible. ${ }^{65}$

David Bohm argued the same idea and introduced the concept of "hidden variables". It will be understood that the quantum world has also a deterministic character when it discovered these hidden variables that are influential in its movements. However, many scientists assert that it is only possible at a philosophical level to advocate such an idea without any experimental data, and it is difficult to accept this claim on the scientific level. ${ }^{66}$ For Bohr, uncertainty stems from our experimental and conceptual limitations, because we encounter phenomena with uncertainty in the process of observation. We can only measure the position of the electron when we look at the electron. We have to light it, so we have to send a photon upon it. However, the photon falling on it pokes the electrons and the speed

${ }^{64}$ Barbour, Issues in Science and Religion, 299-300.

65 Davies, Tanrı ve Yeni Fizik, 140. Davies,

66 Barbour, Issues in Science and Religion, 300. 
of the electron changes in a way that we can not control. Using shorter light waves does not change the situation. In the same way, these waves change the speed of electrons because they are highly energized. Thus, it is impossible to measure the actual speed, and so, disturbing the system is inevitable, because a small interaction between observation and observer is necessary. ${ }^{67}$

Another argument put forward in this regard is "conceptual inadequacy". Accordingly, existing concepts which we use to describe the entity are concepts based on common sense that we have gained from our experience. Using these concepts in describing the subatomic world has some limitations. For this reason, our experimental and conceptual limitations will never allow us to know whether the atom can actually be determined or not. ${ }^{68}$ As it is clear from these statements, this is a totally agnostic approach. The main difference between the first and the second approach is that while the first says that one day we will have scientific equipment to discover the deterministic nature of subject; and the second asserts that we will never know the truth of the matter.

These three approaches to the uncertainty principle, unlike Copenhagen interpretation, means that Quantum does not completely eliminate the principle of causality, but only weakens the strict determinism. Hawking, one who defends this, although defending that quantum indeterminacy originates from the nature of the matter, notes that the uncertainty principle seems to be a threat to determinism, but it is actually not. This is because determinism continues to be used in a new theory with its form containing the uncertainty principle and it is called quantum mechanics. First of all, roughly half of what is expected to be predicted by Laplace determinism, position or velocity, can be predicted precisely in quantum mechanics. We do not foresee both the positions and velocities of particles at the same moment, but we can predict the wave functions. If we know the wave function of a particle at a certain moment, it may be possible to calculate its past and future. It is still possible to argue that there is determinism within this restricted area. For this reason " the quantum theory is still deterministic, but this is a diminished scale". 69

According to Hawking, however, quantum physics has partly a

\footnotetext{
67 Niels Bohr, Essays 1958-1962 on Atomic Physics and Human Knowledge (London: Interscience Publishers, 1963), 3-5; Barbour, Issues in Science and Religion, 301.

68 Barbour, Issues in Science and Religion, 302-303.

${ }^{69}$ Hawking, The Universe in a Nutshell, 106-108.
} 
deterministic character, because, with regard to particle theories, if the condition of the wave is known at a certain moment, it can be calculated for another moment. It is unpredictable when we try to interpret the wave only in terms of the position and velocity of the particles. Whereas maybe this is wrong and there's no such a thing as the speed and position of the particle, maybe there is only the wave. We may be faced with uncertainty as we try to fit the wave into the thought patterns of position and velocity that we have previously grasped. 70

Planck admitted that it is not possible to continue or generalize the causality law with its classical content after quantum physics. According to him, statistical lawfulness is valid in quantum mechanics. ${ }^{71}$ The cause of uncertainty stems from the fact that this electron is seen as a particle as it is in classical physics. If the electron is regarded as a wave, not as a particle, it may be possible to establish a deterministic theory, ${ }^{72}$ because the wave function can be precisely defined for every moment and every position by means of initial and environmental conditions. In this case, the uncertainty principle does not mean that it is impossible to determine the position of the electron, but at the same time there is no specific place. Hence, in an actual sense, the electron is not found anywhere or it is everywhere. Thence, the orbital question of electrons becomes meaningless.

Barbour argues that a critical realist approach to the interpretation of the uncertainty principle is more coherent. Accordingly, quantum theory can be defended as a scientific theory that is quite different from daily life, but that does not mean that it is less real than the world we are experiencing. Barbour accepts that, like Hawking and Laplace, electrons do not have a certain position and speed. Uncertainty does not derive from the problem of measuremant or our ignorance, but rather because of the nature of the matter. There is no definite causal relationship between observation and observer, but the measurement action causes one of the possibilities already existing in the nature of matter to be realized. Therefore, the role of the observer does not have disturbing effect on the movement of electrons, but it forces it to realize one of the possibilities that it potentially holds. ${ }^{73}$ In this case, it is both accepted that the indeterminacy is an ontological reality and there is existence of causal relations at the subatomic world.

\footnotetext{
${ }^{70}$ Hawking, A Brief History of Time, 150.

71 Planck, Modern Doğa Anlayışı ve Kuantum Teorisine Giriş, 74, 163.

72 Planck, Modern Doğa Anlayıșı ve Kuantum Teorisine Giriș, 104-105.

${ }^{73}$ Barbour, Issues in Science and Religion, 303-304.
} 
In this regard, Heisenberg suggested that Aristotle's concept of "potential" can help to understand the probabilistic scructure of quantum. But the concept of potential expresses the tendency of an entity to exhibit behavior in a certain direction in Aristotelian interpretations. However, according to Heisenberg, the concept of potential in modern physics refers to the tendency of nature to include a number of possibilities. ${ }^{74}$ That is to say, when we take into account the potential-actual concepts of Aristotle, the probability wave means a potential with a range of possibilities in the quantum uncertainty principle. With the influence of the observer, one of the possibilities becomes real, that is, the collapse occurs. ${ }^{75}$

Turkish physicist Yilmaz Oner, who was a student of Heisenberg for a while, has developed The Theory of Pro-determinism (probabilistic determinism) instead of rough determinism, based on these view of his teacher. Öner does not regard the matter as a completed phenomenon but as a general "production system" in constant change. According to the understanding of pro-deterministic causality, the nature of the substance is a virtual possibilities store. Accordingly, the objective reality category is divided into virtual reality and actual reality. That is, there is a doublecategorized ontological reality. Actual reality is a form of virtual possibilities in which one is preferred and actualized by nature within a certain possibilities. All the actualized things that occur in this way, all together form the actual universe. For all actual things, there is a certain life-sustenantation (lifetime). The universe is a whole with actualized facts and virtuels that have not yet reached actual reality. From the actual reality to the virtual reality, and vice versa, there is a mutual and continuous process of coming and going from the virtual reality to the actual reality. Both worlds are subject to a prodeterministic certainty, a universal determinism. ${ }^{76}$

As a result, we can say that it is not correct, the common belief moving from the data of quantum theory, that the causal relations in the atomic world are totally invalid and there is no reason for the movements of atoms and electrons. Quantum physics only reveals that results can not be precisely predicted in advance and the results are not necessarily determined by the causes, because, being something "causeless" expresses its emergence for the first time, regardless of anything else. However, events in the subatomic world occur within particular possibilities, and these possibilities are

74 Heisenberg, Physics and Philosophy, 107, 124.

75 Şevki Işıkll, Kuantum Mekaniği İlkelerinin Felsefi İçerimleri (Ankara: Ankara University Institute of Social Science, PhD Thesis, 2012), 200.

76 M. Yılmaz Öner, Prodeterminizm (İstanbul: Belge Publications, 2000), 99 ff. 
determined by previous wave functions. However, it is clear that the existence of a precise and deterministic causality can not be mentioned in this process. With reference to Barbour's words, it is possible to call such a relation as a "weak causality relation", 77 because the strong causality in the Newtonian mechanics loses its validity under the Planck level. For this reason, the most optimistic form of determinism, which may be valid in quantum mechanics, may be "weak causality".78

This is due to the fundamental differences between classical physics and quantum physics. It is possible to summarize these differences as follows: Classical mechanics is deterministic in the point of prediction and it is atomistic in point of comprehension. Quantum mechanics, on the other hand, is probabilistic in the point of prediction and holistic in the point of comprehension. ${ }^{79}$ Unlike classical mechanics in quantum mechanics, the system and the observer have no independent reality from one another. The external observer of the classical physics is considered to be a participant observer as a part of the experiment in quantum physics. ${ }^{80}$ Determinism, certainty, locality, objectivity and separability of subject and object in classical physics leaves its place in quantum physics to indeterminacy, uncertainty, nonlocality, and the absence of objectivity, being independent from observation and holism. ${ }^{81}$

In our opinion, soft-deterministic interpretation of quantum physics compatible with both the Basra school's and the Al-Nazzām's understanding of causality. Because in this approach, it is possible both to preserve the order in the universe and to argue that this order can be violated by a divine force when necessary (e.g. for miracles).

\section{Conclusion}

In our opinion, a new reading that takes into account modern physics based on the causality theories of mutakallimūn is possible. If we follow the interpretations of Islamic causality, it is God who choses between the possibilities mentioned in quantum physics. God pushes the wave function to collapse on a specific state out of many possible states, He is the converter of the epistemological to be ontological, the potential to actual and the absence to presence. We can express this process in that, by borrowing the

77 Barbour, Issues in Science and Religion, 304.

78 Petr Hâjîcêk, "Liberties in Nature: On Photons, Bugs and Chess Players", arXiv:physics/0608275v3 [physics.class-ph] 28 Nov 2006, (2006), 9.

79 Verçin, "Harekete İki Farklı Bakış", 2.

80 Ișılkl, Kuantum Mekaniği İlkelerinin Felsefi İçerimleri, 184.

81 Işılklı, Kuantum Mekaniği İlkelerinin Felsefi İçerimleri, 170. 
concepts of al-jawhar (atom) and al-ā'rād (accident) of the mutakallimūn and al-Naẓzām's concept of kumūn (latency)-zuhūr (occurrences): the electron, like jawhar, does not have qualities like position and speed, but it is only a wave. Hence, as it has no dimension, it has not a real existence too, until the wave function collapses and it possesses attributes such as position and velocity. All possibilities contained in these wave functions can be described as epistemological possibilities (potential) hidden (kumūn) in the matter. The fact that actualizing and appearing (zuhūr) one of them brings the actual matter to light.

The role of God here, if we follow quantum interpretations, is the collapse of the wave function and the cause of both the electron and the observer to exist (creation) when the observation is made. If the presence of such a decision maker would not accept it, no one of these possibilities have enough reasons to take place. One of these possibilities collapses with the preference and creation of God and in this way the objects emerge into the field of existence. It can be possible for objects which get attributes in this way to be changeable and effective on other objects through these attributes. The process of creation happens in a specific order in accordance with God's will. As for the miracles, God creates one of the least possibilities in contradiction to what we are accustomed. As a result, in such an assumption, it is assumed that both the principle of causality in nature and beings have innate natures. This, in turn, rejects an strict deterministic structure stemming from the nature of beings, but allows the acceptance of divine acts and miracles.

\section{REFERENCES}

ABŪ ZAYD, Munā Ahmad. al-Tasawwur al-dharrī fĩ al-fikr al-falsafí al-Islāmī. Beirut: al-Muassasa al-Jâmiiyya, 1994.

AL-ASH'ARĪ, Abū Al-Hasan. Maqālāt al-Islāmiyyīn wa ikhtilāf al-muṣallīn. ed. M. Muhyiddin Abdülhamid. Cairo: Maktaba al-Nahdiyya al-Misriyya, 1955.

AL-BAGHDĀDĪ, 'Abd al-Qāhir. al-Farq bayn al-firaq. ed. M. Uthmān Al-Husht. Cairo: Maktaba Ibn Sīnā, 1988.

AL-FĀRĀBĪ, Abū Nașr. Arāu ahl al-Madīna al-fāḍila. ed. A. Nasri Nader. Beirut: Dār al-Mashrik, 1986.

AL-GHAZĀLĪ̄, Abū Ḥāmid. Tahāfut al-falāsifa. ed. Mahmut Kaya-Hüseyin Sarıŏlu. İstanbul: YEK Publications, 2014. 
AL-JUWAYNĪ, Imām al-Ḥaramayn. Kitāb al-Irshād ilā kawāți' al-adilla fì usūl al-i'tikād. ed. Ahmad Abd al-Rahman al-Sāyih-Tavfik Ali Vahba. Cairo: Maktaba al-Sakāfe al-Dīnīyya, 2009.

AL-KHAYYĀṬ, Abu al-Husayn. al-Intișār wa al-radd 'alā Ibn al-Rāwandī almulhid. ed. H. S. Nyberg. Beirut: Makta al-Dâr al-'Arabiyya li al-Kitâb, 1993.

AL-MĀTŪRĪDĪ, Abū Manșūr. Kitāb al-Tawhīd. ed. Bekir TopaloğluMuhammed Aruçi. 18 Cilt. İstanbul: TDV Publications, 2001.

AL-MĀTŪRĪDĪ, Abū Manșūr. Ta'wilāt al-Qur'ān. ed. Bekir Topaloğlu. 18 Cilt. İstanbul: Dār al-Mīzān, 2005.

AL-NASAFĪ, Abū al-Mu'īn. Tabșira al-adilla fì al-ușūl al-dīn. thk. Hüseyin AtayŞaban Ali Düzgün. Ankara: DİB Publications, 2004.

AL-NĪSĀBŪRĪ, Abū Rashid. Kitāb al-Masāil fì al-khilāf bayna al-Bașriyinn waal-Baghdādiyyīn. ed. Ma'an Ziyāda-Ridwān al-Sayyid. Beirut: Ma'had al-Anmā' al-'Arabī, 1979.

AL-SHAHRISTĀNĪ, Abu al-Fatḥ. al-Milal wa al-niḥal. ed. Abū 'Ali Mahnā-'Ali Hasan Fā'ūr. Beirut: Dār al-Ma'rifa, 1993.

AL-SHAYKH AL-MUFĪD. Awāil al-maqālāt. thk. Ibrāhim al-Anșārī. Mashad: alMu'tamar al-'ālam, 2000.

ALTAIIE, Basil. God, Nature, and the Cause: Essays in Islam and Science. USA: Kalam\&Research Media, 2016. https://www.goodreads.com/book/show/32991750-god-natureand-the-cause

ALTAIE, Basil vd. "Mafhūm al-sababiyya fĩ al-fizyā al-mu'āsira wa 'inda almutakallimīn al-muslimīn". Kutadgu Bilig 23/ (2013), 255-294.

ALTAIE, Basil. "Re-Creation: A Possible Interpretation of Quantum Indeterminism". ArXiv:0907.3419v2 [Quant-Ph] 23 Jul 2009, 1-18.

ARÍSTOTELES. Fizik. çev. Saffet Babür. İstanbul: Yapı Kredi Publications, 2005.

ARISTOTELES. Metafizik. çev. Ahmet Arslan. İstanbul: Sosyal Publications, 1996.

ARSLAN, Ahmet. İlkçağ Felsefe Tarihi 1 Sokrates Öncesi Yunan Felsefesi. İstanbul: İstanbul Bilgi Üniversitesi Publications, 2006.

AYDIN, Hasan. Eski Yunan'dan İslam'ın Klasik Çağına Neden Kavramı ve Nedensellik Sorunu. İstanbul: Bilim ve Gelecek Publications, 2009.

BARBOUR, Ian G. Issues in Science and Religion. USA: Prentice-Hall, 1966. 
BOHR, Niels. Essays 1958-1962 on Atomic Physics and Human Knowledge. London: Interscience Publishers, 1963.

BULĞEN, Mehmet. Kelam Atomculuğu ve Modern Kozmoloji. İstanbul: Türkiye Diyanet Vakfı Publications, 2015.

DAVIES, Paul. Tanrı ve Yeni Fizik. çev. Barış Gönülşen. İstanbul: Alfa Publications, 2013.

DEMIR, Osman. "Determinizm ve Okasyonalizm Arasında: Mu'tezile'de Tevlid Düşüncesi ve Ehl-i Sünnetin Eleştirisi”. Marmara Üniversitesi Illahiyat Fakültesi Dergisi 36 (2014), 63-82.

DEMIR, Osman. Kelâmda Nedensellik Illk Dönem Kelamcılarında Tabiat ve Insan. Klasik Publications, 2015.

DEVJI, Umit Yolsuloglu. "AI-Ghazāli and Quantum Physics: A Comparative Analysis of The Seventeenth Discussion of Tahāfut al-Falāsifa and Qantum Theory". Canada: McGill University Institute of Islamic Studies, MA Thesis, 2003.

DHANANI, Alnoor. "Al-Mâtûrîdî and Al-Nasafî on Atomism and the Tabâi"'. Büyük Türk Bilgini İmâm Mâtûrîdî ve Mâtûrîdîlik. ed. İlyas Çelebi. 6576. İstanbul: M.Ü. İlahiyat Fakültesi Vakfı Publications, 2012.

DHANANI, Alnoor. "Atomism in Islamic Thought". Encyclopaedia of the History of Science, Technology, and Medicine in Non-Western Cultures. ed. Helaine Selin. 379-381. Dordrecht: Springer Netherlands, 2008. https://doi.org/10.1007/978-1-4020-4425-0_8463

DHANANI, Alnoor. The Physical Theory of Kalām: Atoms, Space, and Void in Basrian Mu'tazilī Cosmology. Leiden: Brill, 1993.

ERDEM, Hüsameddin. İlkçağ Felsefesi Tarihi. Konya: Hü-Er Publications, 2010.

ERDEMCI, Cemalettin. Kelam Kozmolojisine Giriş. Ankara: Araştırma Publications, 2007.

FEYNMAN, Richard. The Character of Physical Law. USA: M.I.T Press, 1985.

GOLSHANI, Mehdi. "Islam and the Sciences of Nature: Some Fundamental Questions". Islamic Studies 39/4 (ts.), 597-611.

GRIBBIN, John. Schrödinger'in Kedisinin Peşinde. çev. Nedim Çatlı. İstanbul: Metis Publication, 2005.

GRIBBIN, John. Schrödinger'in Yavru Kedileri: Gerçekliğin Peşinde. çev. Nedim Çatl. İstanbul: Metis Publication, 2008.

HÂJîCÊK, Petr. "Liberties in Nature: On Photons, Bugs and Chess Players". 
arXiv:physics/0608275v3 [physics.class-ph] 28 Nov 2006, 1-28.

HARDING, Karen. "Causality Then and Now: Al Ghazālī and Quantum Theory". The American Journal of Social Sciences 10/2 (1993), 165177.

HAWKING, Stephen. A Brief History of Time. New York: Bantam Press, 1996.

HAWKING, Stephen. The Universe in a Nutshell. London: Bantam Press, 2001. HEISENBERG, Werner. Physics and Philosophy. London: Penguin Books, 2000.

IBN MAYMŪN, Abū 'Imran Mūsā. Dalālat al-hā'irīn. Ankara: AÜíF Publications, 1974.

IBN SīNĀ, Abū 'Alī. Kitāa al-Shifã Metaphysic. çev. Ekrem Demirli-Ömer Türker. İstanbul: Litera Publications, 2004.

IŞIKLI, Şevki. "Kuantum Mekaniği İlkelerinin Felsefi İçerimleri". Ankara: Ankara University Institute of Social Science, PhD Thesis, 2012.

KANDEMİR, Ahmet Mekin. Mu'tezili Düşüncede Tabiat ve Nedensellik. İstanbul: Endülüs Publications, 2019.

KAZANÇ, Fethi Kerim. Kâdî Abdülcebbâr'da Nedensellik Kuramı. Ankara: Araştırma Publications, 2014.

KRANZ, Walter. Antik Felsefe: Metinler ve Açılklamalar. çev. Suat Baydur. İstanbul: Sosyal Publications, 1994.

MUHTAROGLU, Nazif. "Al-Mātūrīdī's View of Causality". Occasionalism Revisited. 3-21. Abu Dhabi: Kalam\&Research Media, 2017.

ÖNER, M. Yılmaz. Prodeterminizm. İstanbul: Belge Publications, 2000.

PENROSE, Roger. Büyük, Küçük ve İnsan Zihni. çev. Cenk Türman. İstanbul: İzdüşüm Publications, 2005.

PLANCK, Max. Modern Doğa Anlayışı ve Kuantum Teorisine Giriş. çev. M. Yılmaz Öner. İstanbul: Spartaküs Publications, 1996.

POLKINGHORNE, John. Quantum Theory A Very Short Introduction. New York: Oxford University Press, 2002.

QĀḌI 'Abd al-Jabbār. Kitāb al-Macmū' fi al-muhịt bi al-taklīf 1. ed. J. J. Houben. Beirut: Matba'a al-Katūlīkiyya, 1962.

QĀḌI 'Abd al-Jabbār. Kitāb al-Tawlīd min kitāb al-mughnī. ed. Osman Demir. İstanbul: Klasik Publications, 2015.

QĀḌ̄ 'Abd al-Jabbār. Sharh al-usūl al-khamsa. ed. İlyas Çelebi. İstanbul: YEK Publications, 2013.

TASLAMAN, Caner. Kuantum Teorisi, Felsefe ve Tanrı. İstanbul: İstanbul 
Publications, 2008.

TAYLOR, Richard. "Causation". The Encyclopedia of Philosophy. ed. Paul Edwards. New York: Macmillan, 1967.

VERÇiN, Abdullah. "Harekete İki Farklı Bakış: Determinizm ve Atomizme Karşı Olasılıkçllık ve Bütünlükçülük". Popüler Bilim 51/ (2001), 1-16.

WOLFSON, H. Austryn. The Philosophy of Kalām. London: Harward University Press, 1976.

YAVUZ, Yusuf Şevki. "Mâtûrîdî’nin Tabiat ve İlliyete Bakışı". Büyük Türk Bilgini İmâm Mâtûrîdî ve Mâtûrîdîlik. 56-64. İstanbul: M.Ü. İlahiyat Fakültesi Vakfı Publications, 2012

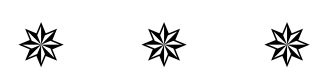




\title{
KELÂMDA VE MODERN FİZİKTE NEDENSELLİK TARTIŞMALARI:

\author{
Tab' Teorisi ile Kuantum Teorisinin Soft- \\ Determinist Yorumları Arasında Bir \\ Karşılaştırma*
}

(1) Ahmet Mekin KANDEMIR ${ }^{\mathrm{a}}$

\begin{abstract}
Geniş Öz
Bu makalede, Müslüman kelâmcıların nedensellik anlayışları modern fizik teorileri açısından ele alınmakta ve bu çerçevede süregelen tartışmalara ilişkin değerlendirmeler yapılmaktadır. Nedensellik konusunda, arada farklı tonlar olmakla birlikte, kelâmda üç farklı anlayışın olduğu görülmektedir. Bunların ilkinde nedensellik ilkesi tümüyle reddedilmektedir. Eş'arîlerin temsil ettiği bu yaklaşımda neden ile sonuç arasındaki ilişkinin zorunlu olmadığı, âlemde meydana gelen tüm değiş̧im ve olayların doğrudan Allah'ın yaratması ve âdetiyle gerçekleştiği savunulmaktadır. Bu yaklaşımın temelinde, onların savunduğu atomculuk doktrininde tüm cevherlerin denk olması, hiçbir arazın sürekli olamaması, Allah'ın dışında hiçbir varlığın yoktan bir şey meydana getirememesi gibi kabuller yatmaktadır. Ayrıca onlar, varlıkların bağımsız işleyen bir tabiata sahip olduğu fikrinin, Allah'ın tabiata müdahalesini ve dolayısıyla mucizeyi imkansız kılacağını düşünmüşlerdir. Nedensellik konusundaki ikinci yaklaşım Mu'tezile'nin Basra ekolüne aittir. Onlar nedensellik ilkesini belli bir ölçüde kabul etmişlerdir. Çünkü onların cevher-araz anlayışında, cevherlerin bazı arazları meydana getirmesi ve bu arazların sürekliliği mümkün olduğu gibi, cisimlerdeki i'timâdlar onların başka cisimler üzerinde tesir meydana getirmesine de imkan verir. Böylelikle nesnelerin birbirini etkilemesi, yani
\end{abstract}

\footnotetext{
${ }^{*}$ Bu çalıșma, Türkiye Bilimsel ve Teknolojik Araștırma Kurumu (TÜBİTAK) tarafından desteklenmiştir. Proje No: 1059B141600845

a Arş. Gör. Dr., Necmettin Erbakan University, ahmetmekin@hotmail.com
} 
neden-sonuç ilişkisi mümkün olmaktadır. Ayrıca onlar tevlîd teorisiyle, bir fâilin fiilinin doğadaki sonuçlarının nedensellik ilkesi gereği zorunlu bir şekilde meydana geldiğini kabul etmişlerdir. Bazı konularda ise işleyişin âdet gereği olduğunu kabul ederek mutlak determizm fikrinden uzaklaşmışlardır. Üçüncü yaklaşım ise Mu'ammer (ö. 215/830), Nazzâm (ö. 231/845), Câhız (ö. 255/869) ve Ka'bi (ö. 319/931) gibi Mu'tezilî âlimlerin savunduğu tabiat/tab' teorisidir. Bu anlayışta nesnelerin Allah tarafından belirli tabiatlar üzere yaratıldıkları ve bu tabiatların bir gereği olarak neden-sonuç ilişkisi içerisinde varlıklarını sürdürdükleri kabul edilmektedir. $\mathrm{Bu}$ isimlerden Nazzâm ve Câhız sebep-sonuç ilişkisinin her durumda zorunlu olarak gerçekleşmeyeceğini, sebep olduğu halde bazı engellerden dolayı sonucun meydana gelmeyebileceğini de vurgulamıștır. Bu yönüyle onlar tabiatların kendi yapılarından kaynaklanan mekanik bir işleyişi reddetmiş, ilahi müdahaleye açık ve mucizenin mümkün olduğu bir evren tasavvurunu savunmuşlardır.

İslam düşüncesinde tabiat ve âdet teorileri etrafında cereyan eden nedensellik tartışmalarının bir benzeri modern fizikte determinizmindeterminizm şeklinde cereyan etmektedir. Newton fiziğinin egemen olduğu bilim çevrelerinde determinizm savunulurken bazı kuantum fizikçileri belirsizlik ilkesinin indeterminist bir evren tablosu sunduğunu ileri sürmektedir. Kopenhag Yorumu olarak da bilinen bu yaklaşıma göre varlığın en temel yapı taşları olan atomaltı parçacıklar bazen parçacık bazen de dalga gibi davrandığından onlara ait hız ve konum gibi niteliklerin tam olarak tespit edilmesi mümkün değildir. Burada ancak olasılıklardan söz edilebilir. Parçacıkların davranışları ölçüldüğünde ise gözlemcinin ve gözlem yapılan aletin etkisi parçacığın davranışını bozmakta ve bu olasılıklardan birinin gerçekleşmesine yol açmaktadır. Öte yandan "kuantum dolanıklı̆̆ı" ve "uzaktan etki" ile ilgili deneylerden elde edilen veriler iki parçacığın uzayzamanda herhangi bir bağlantı olmaksızın uzaktan etkiyle birbirilerini etkileyebileceği ortaya konmuştur. Bu durum klasik fizikteki nedensellik ilkesinin tümüyle ihlal edilmesi anlamına gelmektedir. Bazı fizikçiler ise atomaltı dünyada nedensel ilişkilerin tümüyle geçersiz olduğu, atomların ve elektronların hareketlerinin herhangi bir nedeni olmadığı şeklindeki yorumların yanlış olduğunu savunmaktadırlar. Onlara göre burada olasılıksal bir determinist bir yapı hala geçerlidir. Çünkü atomaltı dünyadaki olaylar belli olasılıklar çerçevesinde meydana gelmekte ve bu olasılıklar da kendisinden önceki dalga fonksiyonları tarafından belirlenmektedir. Kuantum fiziği ise sadece sonuçların önceden kesin olarak öngörülemeyeceğini ve nedenlerin sonuçlar tarafından zorunlu olarak 
belirlenmediğini ortaya koymaktadır.

Şimdiye kadar yapılan çalışmalarda genellikle Kopenhag Yorumu ile âdet teorisi karşılaştırılmış ve iki teorinin büyük ölçüde örtüştüğü savunulmuştur. Bu makalede ise varlıklardaki tabiatları ve nedenselliği kabul eden kelamcıların teorileri teorileri ile Kuantum fiziğinin softdeterminist yorumları karşılaştırılmaktadır. Buradan hareketle de modern fiziği dikkate alan yeni bir okuma önerilmektedir. Nazzâm'ın kumûn-zuhūr kavramlarını ve atomcu kelamcıların cevher-araz kavramlarını ödünç alarak bunu şöyle ifade edebiliriz: Elektron, tıpkı cevher gibi konum ve momentum gibi niteliklere sahip değildir, sadece belli olasılıklara sahiptir. Dolayısıyla, boyutu olmadığı için, dalga fonksiyonu çökünceye, yani konum ve hız gibi niteliklere sahip oluncaya kadar gerçek bir varlığı da yoktur. Bu dalga fonksiyonlarında bulunan tüm olasılıklar, maddede gizli (kumûn) potansiyel olasılıklar olarak tanımlanabilir. Bunlardan birinin ortaya çıkması ve aktüel hale gelmesi maddenin de gerçek anlamda var olması anlamında gelir. İslam düşüncesinde, sözü edilen olasılıklar arasında seçim yapan, dalga fonksiyonunun çökmesini sağlamayan ve hem gözlemcinin hem de hem de nesnenin aktüel bir gerçeklik olarak var olmasını sağlayan Allah'tır. Böyle bir karar vericinin varlığı kabul edilmezse, bu olasılıklardan hiçbiri gerçekleşmek için yeterli bir sebebe sahip olamaz. Bu şekilde nitelik kazanan nesnelerin, bu nitelikler aracılığıla diğer nesneler üzerinde etkili olması mümkündür. Mucizelere gelince, Allah normalde görmeye alışık olduğumuz durumla çelişen en düşük olasılığı yaratarak mucizeleri meydana getirebilir. Sonuç olarak böyle bir varsayımda hem doğadaki nedensel ilişkiler hem de varlıkların belli tabiatlara sahip olduğu kabul edilmiş olur. Bu da varlıkların tabiatlarından kaynaklanan mutlak determinist bir yapıyı reddetmekle birlikte ilahi fiiller ve mucizeleri kabul etmeye imkan sağlar.

Anahtar kelimeler: Kelâm, Nedensellik, Tabiat (tab') teorisi, Âdet teorisi, Kuantum fiziği.

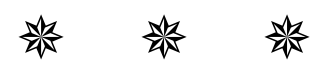

